\title{
ХРОНИКА
}

УДК 551

\section{К 90-летию Клары Андреевны Горбуновой}

\section{Н.Г. Максимович, О.Ю. Мешерякова}

Естественнонаучный институт Пермского государственного национального исследовательского университета, 614990, Пермь, Генкеля, 4

E-mail: nmax54@gmail.com, olgam.psu@gmail.com

(Статья поступила в редакциюю 20 августа 2015 г.)

Статья посвящена юбилейной дате - исполнилось 90 лет со дня рождения Клары Андреевны Горбуновой, яркого представителя известной во всем мире пермской школы карстоведения. Приведены данные о ее научной, издательской, педагогической, редакционной деятельности.

Ключевые слова: К.А. Горбунова, карст, пещеры, спелеология, карстоведение.

DOI: 10.17072/psu.geol.29.93

Клара Андреевна Горбунова - яркий представитель известной во всем мире пермской школы карстоведения. Ее фундаментальные работы по карсту и спелеологии вошли в золотой фонд российской и мировой науки. Ее имя известно за рубежом, результаты исследований широко используются в России и во многих странах мира [14].

Клара Андреевна родилась 3 декабря 1925 г. в с. Новая Заимка Тюменской области. Позже переехала на Урал, окончила школу с отличным аттестатом. 1 сентября 1943 г. была зачислена на I курс геологогеографического факультета Пермского государственного университета.

В 1948 г. К. А. Горбунова с отличием окончила университет и поступила в аспирантуру на базе кафедры динамической геологии и гидрогеологии по специальности «Общая геология». 30 мая 1956 г. Клара Андреевна защитила кандидатскую диссертацию на тему «Карст некоторых районов Пермской области», в которой было проведено районирование карста и охарактеризованы закарстованные территории области.

С 1 сентября 1956 г. доцент кафедры, читала основной курс «Общая геология» и спецкурсы, руководила дипломными ра- ботами и производственной практикой студентов. 11 апреля 1959 г. решением ВАК СССР была утверждена в ученом звании доцента.

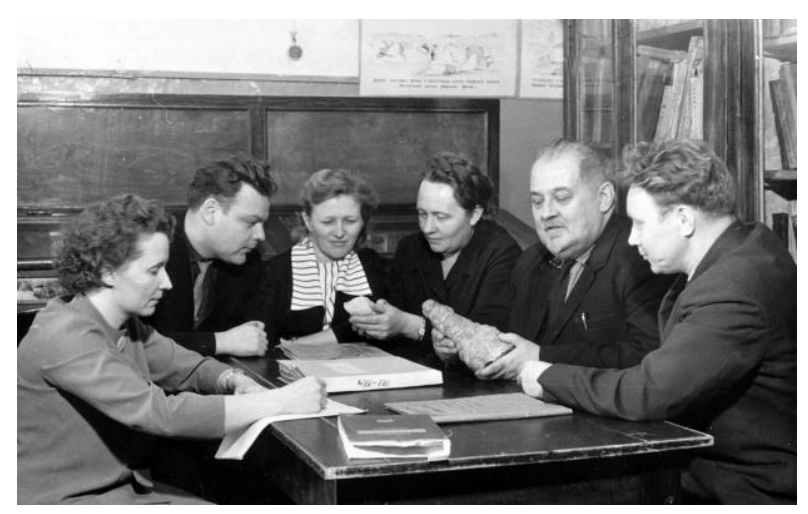

12 декабря 1965 г. Кафедра динамической геологии и гидрогеологии Пермского университета. Слева направо: лаборант Н.А. Глухих, доц. Г.К. Михайлов, асс. Р.В. Ященко, доц. К.А. Горбунова, проф. Г.А. Максимович, доц. И.А. Печеркин

Различные обстоятельства не позволили Кларе Андреевне подготовить докторскую диссертацию и получить звание профессора. Однако ее авторитет, особенно за рубежом, был настолько высок, что многие зарубежные коллеги считали ее профессором, присвоив ей это звание «по совокупности работ». Достаточно по- 
смотреть на ее обширную международную переписку и ссылки на работы «профессора К. А. Горбуновой» на зарубежных сайтах Интернета.

Свою первую научную работу К. А. Горбунова опубликовала в известном российском журнале «Природа» в 1950 г. Она посвящена карсту с. Кишерть. В последующие годы карст стал ее главным научным интересом. Всего К. А. Горбуновой опубликовано 328 научных, научно-методических, научнопопулярных работ общим объемом около 150 печатных листов. Среди них 8 монографий: «Карст Пермской области» (1958) [11]; «Особенности гипсового карста» (1965) [2]; «Карст гипса СССР» (1977) [3]; «Морфология и гидрогеология гипсового карста» (1979) [4]; «Карстоведение. Вопросы типологии и морфологии карста» (1985) [5]; «Техногенное воздействие на геологическую среду Пермской области» (1990) [10], «В мире карста и пещер» (1991) [9], «Карст и пещеры Пермской области» (1992) [7]; а также глава «Озера карстовых районов» в фундаментальной двухтомной монографии Г. А. Максимовича «Основы карстоведения» (1969. Т. 2) [13].

Клара Андреевна была специалистом широкого профиля. Большое внимание уделяла карстоведению, спелеологии, экологии.

Карстоведение. Изучение карста - дело всей жизни К. А. Горбуновой. Следует отметить, что ее работы по гипсовому карсту практически сразу стали классическими и до сих пор являются единственными крупными обобщениями в этой области.

Она занималась очень сложной проблемой - районированием карста. Ею впервые проведено типологическое районирование карста СССР, предложены принципы выделения мегатипов закарстованных территорий и обстановок карстообразования. Приняла участие и в подготовке карты распространения пород CCCP, изучала направленность изменения земной коры в областях развития карста
[8]. Ею рассматривались тектоническая зональность карста, формирование нового типа четвертичных отложений - карстовой брекчии [16].

В работах К. А. Горбуновой освещены геологические предпосылки развития сульфатного карста на территории СССР [3], в Восточносибирском и Среднеазиатском регионах, в Нечерноземной зоне, в Пермском крае и, в частности, в Кишертско-Суксунском районе [2]; морфология, гидрогеология и гидрогеохимия сульфатного карста [4, 5, 17]; поверхностные формы и их эволюция; гипсовая тектоника.

Ею рассмотрены геологические предпосылки развития карбонатного карста Приуралья и Среднеазиатского региона; вопросы типологии и морфологии [5]; особенности формирования известковых туфов (калькитов).

К. А. Горбуновой детально изучен карст Полазненского, Кизеловского, Чусовского районов. Рассматривались закономерности распределения карста [1], его практическое значение. Под ее руководством в 1990 г. составлена «Карта пород и карста Пермской области» в масштабе 1: 500 000, которая широко используется изыскательскими, проектными и производственными организациями. Проблемы карста Пермской области рассматриваются в монографических работах $[7,11]$.

Спелеология. К. А. Горбунова рассматривает содержание спелеологии как науки и основные направления ее развития [6], проблему спелеогенеза, особенности исследований пещер, результаты спелеологических исследований в Югославии и Гватемале. Она дает краткую, но очень содержательную характеристику подземного мира в «Горной энциклопедии» [6]; пишет большую научно-популярную работу о мире карста и пещер [9].

Кларе Андреевне принадлежат как постановочные работы о комплексном изучении отложений карстовых полостей, так и работы, в которых изучаются отдельные аспекты проблемы: геохимия и эпигенетическая трещиноватость глинистых от- 
ложений, акцессорные минералы и люминесценция карбонатных натеков; плотины карстовых полостей и пещерный жемчуг; морфология пещерных льдов.

Экология. К. А. Горбунова одной из первых привлекла внимание к загрязнению подземных вод сельских и городских населенных пунктов Пермского края [12]. Вопросы экологии рассматриваются ею в аспектах изменений состояния геологической среды при проведении нефтепоисковых, горнодобывающих, гидрогеологических работ, при строительстве и эксплуатации промышленных объектов [15]. Отдельно исследуются вопросы техногенного воздействия на геологическую среду Пермского края [10].

Педагогическая и научнообщественная деятельность. За 45 лет педагогической деятельности К. А. Горбунова приняла участие в подготовке большого числа специалистов в области гидрогеологии, инженерной геологии, геофизики и ряда других специальностей. В отдельные годы ее учебная нагрузка составляла до 1000 часов. Руководила двумя студенческими научными кружками: по общей геологии и гидрохимии. Проводила олимпиады, читательские конференции, руководила одной из секций городской олимпиады по геолого-географической тематике.

Клара Андреевна вела большую научно-общественную работу. Особо следует отметить ее работу в Институте карстоведения и спелеологии, основанном по инициативе профессора Г. А. Максимовича на общественных началах 18 ноября 1964 г. группой членов Географического общества СССР. В то время институт был первым в СССР и шестым в мире и объединял 38 специалистов, ведущих исследования по карсту и спелеологии. Клара Андреевна была активным сотрудником института со дня его основания, заведовала отделом геоморфологии. В июне 1979 г. она стала заместителем директора, а в январе 1992 г. - директором института.

\section{Редакторскую}

деятельность малась ею практически постоянно. В 1961-1964 гг. была ответственным редактором сборников «Химическая география» и «Химическая география и гидрогеохимия». Следующей крупной редакторской работой стала подготовка к печати коллективного труда «Химическая география вод и гидрогеохимия Пермской области».

Она входила в состав редколлегий трудов многих совещаний, проводившихся в Перми в 1958-1994 гг. по различным геологическим проблемам. В течение 32 лет (1961-1993) являлась членом редколлегии сборника «Пещеры», в том числе 19 лет была его ответственным редактором (1974-1993). В 1964-1975 гг. Клара Андреевна - член редколлегии сборника «Гидрогеология и карстоведение» (6 выпусков); в 1991-1994 гг. - Вестника Киевского карстолого-спелеологического центра «Свет»; в 1993 г. - сборника докладов Международного симпозиума «Инженерная геология карста».

К. А. Горбунова неоднократно поощрялась благодарностями и грамотами. На юбилейном $\mathrm{X}$ съезде географического общества в августе 1995 г. ей было присвоено звание «Почетный член Русского географического общества».

Клара Андреевна скончалась 18 апреля 1996 г. на 71-м году жизни, оставив после себя огромное научное наследие, без которого невозможно представить себе нынешнее развитие карстоведения и спелеологии.

\section{Библиографический список}

1. Горбунова К. A. Типы карста и факторы карстообразования на примере карстовых районов Пермской области // Зап. Перм. отд. геогр. о-ва СССР. 1960. Вып. 1. С. 25 45.

2. Горбунова К. A. Особенности гипсового карста. Пермь: Перм. книж. изд-во, 1965. $120 \mathrm{c}$.

3. Горбунова К. А. Карст гипса СССР: учеб. пособие по спецкурсу. Пермь: Изд-во Перм. ун-та, 1977. 84 с. 
4. Горбунова К. А. Морфология и гидрогеология гипсового карста: учеб. пособие по спецкурсу / Перм. ун-т. Пермь, 1979. 95 с.

5. Горбунова К. А. Карстоведение. Вопросы типологии и морфологии карста: учеб. пособие по спецкурсу / Перм. ун-т. Пермь, $1985.88 \mathrm{c}$.

6. Горбунова K. A. Спелеология // Горная энциклопедия. М., 1991. Т. 5. С. 52-53.

7. Горбунова К.А., Андрейчук В.Н., Костарев В.П., Максимович Н.Г. Карст и пещеры Пермской области. Пермь: Изд-во Перм. ун-та, 1992. 200 с.

8. Горбунова К. А., Максимович Н. Г. Направленность изменения земной коры в областях развития карста // Роль подземной гидросферы в истории Земли: тез. докл. Всесоюз. семинара. 1989. С. 80-82.

9. Горбунова К. А., Максимович Н. Г. В мире карста и пещер. Пермь, 1991. 120 с.

10. Горбунова К. А., , Максимович Н. Г., Андрейчук $B . H$. Техногенное воздействие на геологическую среду Пермской области / УрО АН СССР. Свердловск, 1990. 40 с.
11. Максимович Г. А., Горбунова К. А. Карст Пермской области. Пермь, 1958. 183 с.

12. Максимович Г. А., Горбунова К. А. Загрязнение грунтовых вод района г. Перми // Гигиена водоснабжения: матер. науч.практ. конф. Пермь, 1966. С. 89-94.

13. Максимович Г. А., Горбунова К. А. Озера карстовых районов // Основы карстоведения. Пермь, 1969. Т. 2, гл. 4. С. 253-382, 506-514.

14. Максимович Е. Г., Максимович Н. Г. Геолог-карстовед К.А. Горбунова (19251996). Пермь: Изд-во «Курсив», 2002. $240 \mathrm{c}$.

15. Максимович Н. Г., Горбунова К. А. Изменение гидрогеологических условий в процессе строительства крупного агропромышленного комплекса // Инженерная геология. 1989. № 5. С. 61-65.

16. Gorbunova K. A., Maximovich N. G. Karst breccias - as a genetic variety of quaternary deposits // Abstracts Int. union for Quaternary research XIII Int. congress. Beijing, China, 1991. P. 117.

\section{On the 90th Anniversary of K. A. Gorbunova}

\section{N.G. Maksimovich, O.Y. Meshcheryakova}

Institute of Natural Sciences of Perm State University. 4 Genkelya Str., Perm 614990, Russia. E-mail: nmax54@gmail.com. E-mail: olgam.psu@gmail.com

The article is devoted to the $90^{\text {th }}$ anniversary since the birth of K.A. Gorbunova, which is a bright representative of the world-known Perm Karst School. The information about her scientific, publishing, teaching, editorial activities is given.

Key words: K.A. Gorbunova, karst, caves, speleology, karstology

\section{References}

1. Gorbunova K.A. 1960. Tipy karsta i factory karstoobrazovaniya na primere karstovykh rayonov Permskoy oblasti [Karst types and factors of karst development on example of the karstic areas of Perm region]. Zap. Perm. otd. geogr. obshch-va USSR. 1:25-45. (in Russian)

2. Gorbunova K.A. 1965. Osobennosti gipsovogo karsta [Characteristics of the gypsum karst]. Perm. Perm Publ., p. 120. (in Russian)

3. Gorbunova K.A. 1977. Karst gipsa SSSR: uchebnoe posobie po spetskursu [Gipsum karst of USSR: Course Notes]. Perm. Perm Univ. Publ., p. 84. (in Russian)
4. Gorbunova K.A. 1979. Morpfologiya i gidrogeologiya gipsovogo karsta: Ucheb. posobie po kursu [Morphology and hydrogeology of gypsum karst: Course Notes]. Perm, Perm Univ. Publ., p. 95. (in Russian)

5. Gorbunova K.A. 1985. Karstovedenie. Voprosy tipologii i morfologii karsta: Ucheb. posobie po spetskursu [Karst studies. Problems of typology and morphology of karst: Course Notes]. Perm, Perm Univ. Publ., p. 88. (in Russian)

6. Gorbunova K.A. 1991. Speleologiya [Speleology]. In Gornaya entsiklopediya. Moskva, T. 5, pp. 52-53. (in Russian)

7. Gorbunova K.A., Andreychuk V.N., Kostarev V.P., Maksimovich N.G. 1992. Karst i pesh- 
chery Permskoy oblasti [Karst and caves of the Perm region]. Perm, Perm Univ. Publ., p. 200. (in Russian)

8. Gorbunova A.K., Maksimovich N.G. 1989. Napravlennost izmeneniya zemnoy kory $\mathrm{v}$ oblasti razvitiya karsta [Tendency of alteration of earth's crust in the karstic areas]. In Rol podzemnoy gidrosfery $\mathrm{v}$ istorii Zemli. Tez. dokl. vsesoyusn. seminara. Leningrad, Ленинград, pp. 80-82. (in Russian)

9. Gorbunova K.A., Maksimovich N.G. 1991.V mire katsta i peshcher [In the world of karst and caves]. Perm, TGU Publ., p. 120. (in Russian)

10. Gorbunova K.A., Maksimovich N.G., Andreychuk B.N. 1990. Tekhnogennoe vozdeystvie na geologicheskuyu sredu Permskoy oblasti [Technogenic influence on the geological environment of Perm region]. Sverdlovsk, UrO RAN USSR, p. 40. (in Russian)

11. Maksimovich G.A., Gorbunova K.A. 1958. Karst Permskoy oblasti [Karst of Perm region]. Perm, p. 183. (in Russian)

12. Maksimovich G.A., Gorbunova K.A. 1966. Zagryaznenie gruntovykh vod g. Permi [Pol- lution of groundwater of Perm area]. In Gigiena vodosnabzheniya. Materialy nauch.prakt. konf. Perm, pp. 89-94. (in Russian)

13. Maksimovich G.A., Gorbunova K.A. 1969. Ozera karstovykh rayonov [Lakes of karstic areas]. In Osnovy karstovedeniya. Perm, T. 2, Gl. 4. pp. 253-382, 506-514. (in Russian)

14. Maksimovich E.G., Maksimovich N.G. 2002. Geolog-karstoved K.A. Gorbunova (19251996) [Geologist-karstolog K.A. Gorbunova]. Perm. Kursiv Publ., p. 240. (in Russian)

15. Maksimovich N.G., Gorbunova K.A. 1989. Izmenenie gidrogeologicheskikh usloviy $\mathrm{v}$ protsesse stroitelstva krupnogo agropromyshlennogo kompleksa [Alteration of hydrogeological conditions in the process of development of large agroindustrial complex]. Inzhenernaya geologiya. 5:61-65. (in Russian)

16. Gorbunova K.A., Maximovich N.G. 1991. Karst breccias - as a genetic variety of quaternary deposits. Abstracts Int. union for Quaternary research XIII Int. congress. Beijing, China, pp. 117. 